Acta vet. scand. $1974,15,256-263$.

From the State Veterinary Medical Institute, Helsinki, Finland.

\title{
OCCURRENCE OF ANTIBODIES TO GROUP SPECIFIC CHLAMYDIA ANTIGEN IN FINNISH SHEEP, CATTLE AND HORSE SERA
}

\author{
By \\ E. Neuvonen and T. Estola
}

\begin{abstract}
NEUVONEN, E. and T. ESTOLA: Occurrence of antibodies to group specific Chlamydia antigen in Finnish sheep, cattle and horse sera. Acta vet. scand. $1974,15,256-263$. - A serological survey on the occurrence of group-specific chlamydial antibodies in random sera of Finnish sheep, cattle and horses was performed. The whole material consisted of 1347 serum samples, including 432 ovine, 454 bovine and 461 equine sera. The sera were sent to the laboratory for various serological tests during 1968-1972. Of the ovine sera $9.5 \%$, bovine $12.8 \%$ and equine $7.1 \%$ showed a titer $\geq 1: 16$ in the complement fixation test.

No definite geographic differences could be found in the distribution of the herds which showed positive results. The ubiquity of chlamydial infections in domestic mammals and their role as a cause of clinical diseases is discussed.
\end{abstract}

ovine chlamydial infections; bovine chlamydial infections; equine chlamydial infections; group specific chlamydial antibodies.

In the winter 1969, an unusually intensive and widespread cough was observed on a fairly big sheep farm in south-west Finland. Clinical examination revealed that the animals had pneumonia. A mioro-organism belonging to the Chlamydia group was isolated from nose swabs and lung specimens of the diseased animals. Paired serum samples from five animals of this farm were investigated serologically, and a positive seroconversion of antibodies to group-specific Chlamydia antigen (gsca) was observed in four of them. In single random samples from 21 sheep of the same stock $16(76 \%)$ had antibodies. This was the first ovine Chlamydia outbreak reported in the Nordic countries (Estola \& Salmela 1970).

Because of this epidemic a serological field study was per- 
formed in which blood samples from 18 Finnish sheep flocks were investigated for gsca antibodies. Positive animals were found in every flock, and 93 of the whole material of 205 samples $(45.4 \%$ ) showed a positive titer (Estola 1970).

The common occurrence of antibodies to gsca has been observed in many animal species throughout the world. Earlier reports dealt mainly with different avian species which were regarded as the most important reservoirs of Chlamydia, but today the main interest is directed to mammals. Chlamydia organisms and/or their antibodies have been found in sheep and many other domestic mammals, such as cattle (Schjerning-Thiesen 1964, Gössler et al. 1973), swine (Wilson \& Plummer 1960, Köbl 1969), horse (Friis 1967, Popovici \& Hiastru 1969) and dog (Fraser et al. 1969, Young et al. 1972). Examples of the global distribution of Chlamydiae are the demonstration of antibodies to gsca in antarctic penguins and seals and also in northern fur seals (Moore \& Cameron 1969), and in arctic Eskimo populations (Wyman et al. 1969).

The epidemiology of Chlamydial diseases in mammals and their pathogenicity to man is still a rather open question. It has been discovered that arthropods and wild rodents can harbour Chlamydiae (Eddie et al. 1969). This finding indicates the presence of sylvatic reservoirs and arthropod vectors for mammalian Chlamydiae. Arthropod vectors have already been suggested for avian strains (Eddie et al. 1962). Concerning the human pathogenicity, there is evidence that the mammalian strains may be transmitted to man (Enright et al. 1958, Krüger-Hansen-Schoop et al. 1966, Roberts et al. 1967), and some bovine strains have been thought to be connected with the aetiopathogenesis of multiple sclerosis (Le Gac 1972). Thus, studies on incidence of Chlamydia infections in domestic mammals and its correlation with Chlamyda infections in man are becoming more and more important.

The results of studies concerning antibodies to gsca in a material of randomly collected serum samples from Finnish sheep, cattle and horses are presented in this report.

Sera

\section{MATERIAL AND METHODS}

Random sera from 432 sheep, 454 cattle and 461 horses were tested for antibodies to gsca. All the ovine sera were obtained 
after the survey of 1969 (Estola 1970) and like the bovine sera were sent to the laboratory for various serological tests, mainly because the animals were to be exported. The equine sera originated partly from quarantine stables for imported horses and partly from horses showing respiratory diseases of various kinds. The material represents about 50 flocks of sheep, 70 herds of cattle and $\mathbf{1 5 0}$ herds of horses, all geographically unselected, from different parts of the country. Only sera from adult animals were included. The ovine sera were sent to the laboratory in $1970-72$, the bovine in 1968-72 and the equine in 1968 and $1970-72$.

The sera were first inactivated at $56^{\circ} \mathrm{C}$ for $30 \mathrm{~min}$. and then stored at $-20^{\circ} \mathrm{C}$ until used.

\section{Assay of antibodies to gsca}

A microtechnique of the direct complement fixation (CF) test was performed. Veronal-buffered saline was the diluent used for all the procedures except the sera which were diluted with saline. Twofold dilutions of serum, two units of antigen and two units of guinea pig complement were mixed. After an incubation period of $18 \mathrm{hrs}$. at $4^{\circ} \mathrm{C}$ the sensitized sheep cells were added and the result was read after $45 \mathrm{~min}$. at $37^{\circ} \mathrm{C}$. The $50 \%$ haemolysis end point was estimated visually and taken as the titer. A titer of 1:16 or higher was considered positive. Sera with any anticomplementary effect were discarded from the material. The antigen used was a commercial ornithos antigen (Behringwerke, Marburg-Lahn ORAR 0809) made from strain P-4.

\section{RESULTS}

Table 1 shows the results for the sheep sera. Antibodies to gsca were found in $41(9.5 \%)$ of the 432 serum samples. The highest incidence $(32.2 \%)$ was in sera submitted to the laboratory in 1971, and the lowest $(6 \%)$ in sera from 1970.

The results of the cattle sera are presented in Table 2. Antibodies were obtained from $58(12.8 \%)$ of the 454 samples. The percentage of positive sera per year varied between 3.0 and 18.4.

The results for the horse sera are presented in Table 3 . Out of the total of 461 sera $35(7.1 \%)$ had antibodies. Over $50 \%$ of the sera from 1968 were positive. This material, 16 sera, represented four horse herds of which two were quarantine stables. 
Table 1. Occurrence of antibodies to group specific Chlamydia antigen in random sera of Finnish sheep.

\begin{tabular}{lcccc}
\hline $\begin{array}{l}\text { Sampling } \\
\text { year }\end{array}$ & $\begin{array}{c}\text { Total number } \\
\text { of sera } \\
\text { examined }\end{array}$ & $\begin{array}{c}\text { Negative } \\
\text { sera } \\
(\leq 1: 8)\end{array}$ & $\begin{array}{c}\text { Positive } \\
\text { sera } \\
(\geq 1: 16)\end{array}$ & $\begin{array}{c}\text { Percentage } \\
\text { of positive } \\
\text { sera }\end{array}$ \\
\hline 1970 & 117 & 110 & 7 & 6.0 \\
1971 & 31 & 21 & 10 & 32.2 \\
1972 & 284 & 260 & 24 & 8.5 \\
\hline Total & 432 & 391 & 41 & 9.5 \\
\hline
\end{tabular}

Table 2. Occurrence of antibodies to group specific Chlamydia antigen in random sera of Finnish cattle.

\begin{tabular}{lcccc}
\hline $\begin{array}{l}\text { Sampling } \\
\text { year }\end{array}$ & $\begin{array}{c}\text { Total number } \\
\text { of sera } \\
\text { examined }\end{array}$ & $\begin{array}{c}\text { Negative } \\
\text { sera } \\
(\leq 1: 8)\end{array}$ & $\begin{array}{c}\text { Positive } \\
\text { sera } \\
(\geq 1: 16)\end{array}$ & $\begin{array}{c}\text { Percentage } \\
\text { of positive } \\
\text { sera }\end{array}$ \\
\hline 1968 & 98 & 80 & 18 & 18.4 \\
1969 & 108 & 95 & 13 & 12.0 \\
1970 & 98 & 80 & 18 & 18.4 \\
1971 & 84 & 77 & 7 & 8.3 \\
1972 & 66 & 64 & 2 & 3.0 \\
\hline Total & 454 & 396 & 58 & 12.8 \\
\hline
\end{tabular}

Table 3. Occurrence of antibodies to group specific Chlamydia antigen in random sera of Finnish horses.

\begin{tabular}{lcccc}
\hline $\begin{array}{l}\text { Sampling } \\
\text { year }\end{array}$ & $\begin{array}{c}\text { Total number } \\
\text { of sera } \\
\text { examined }\end{array}$ & $\begin{array}{c}\text { Negative } \\
\text { sera } \\
(\leq 1: 8)\end{array}$ & $\begin{array}{c}\text { Positive } \\
\text { sera } \\
(\geq 1: 16)\end{array}$ & $\begin{array}{c}\text { Percentage } \\
\text { of positive } \\
\text { sera }\end{array}$ \\
\hline 1968 & 16 & 7 & 9 & 56.0 \\
1970 & 174 & 157 & 17 & 10.0 \\
1971 & 202 & 198 & 4 & 2.0 \\
1972 & 69 & 64 & 5 & 7.2 \\
\hline Total & 461 & 426 & 35 & 7.1 \\
\hline
\end{tabular}

For the rest of the material the percentage of positive horse sera per year varied between 2 and 10.

One hundred and thirty-four (10\%) of the total material of 1347 animal sera were positive. The highest titer value was $1: 32$, which was observed in sera from all the three animal species. Most of the sera (84\%) showed a titer of $1: 16$.

No definite geographic differences could be found in distribution of the animal flocks which showed positive results. 


\section{DISCUSSION}

The CF test was the method chosen for antibody assay. All Chlamydia strains have a common group-specific antigen which fixes complement in the presence of specific antibodies. Thus a positive CF result means only an antibody response to some strain belonging to the Chlamydia group, but does not reveal any strain or species specificity.

The production of type-specific chlamydial antigens has hitherto been so difficult that for the present the $\mathrm{CF}$ test is the only method suitable for serological surveys of this group. Antibodies to gsca can also react with antigens prepared from Herellea (B. anitratum) strains or from normal chicken yolk sac, but it has never been observed that this kind of antigens causes active antibody production in animals in natural conditions (Kinjo d Bankowski 1966, Maierhofer \& Storz 1969). Therefore, the CF test is commonly considered a reliable method for diagnosing Chlamydia infections. However, a drawback of this test is that after the infection the response to gsca can in some animals start rather late and irregularly. This is true especially of young animals (Bassan \& Ayalon 1971, Storz et al. 1971).

The present results show that Chlamydia infections appear in Finland not only in sheep but also in cattle and horses, and that these infections seem to be spread throughout the country. Because of the heterologous background of the material and the lack of paired serum samples, it is not possible to draw conclusions on the correlation between clinical diseases and serologically positive results. A positive correlation in sheep flocks has been reported earlier (Estola 1970), and there are also observations suggesting that positive seroconversions of antibodies to gsca have been developed in some cattle herds after clinical symptoms of pneumoenteritis (Neuvonen $\&$ Estola, unpublished data). Thus Chlamydia infections in Finnish cattle can resemble the same infections in sheep. The correlation between clinical diseases and Chlamydia infections in Finnish horses is still an open question. Popovici \& Hiastru (1969) reported a respiratory disease epizootic of Chlamydia in a horse population which was diagnosed both serologically and by successful isolations of the organism.

The exceptionally high percentage of positive horse sera in the year 1968 is due to the very limited material from that year. The whole material derived from four stables only and they were all infected with Chlamydia. 
The number of positive animal flocks has not been stated here, because the sampling from the different flocks was not performed with the same statistical accurary, and therefore the flock diagnoses are not mutually comparable.

The occurrence of positive sheep sera from 1970 to 1972 varied between 6.0 and $32.2 \%$. This was a clear decrease compared with 1969 (Estola) when $54.7 \%$ of the animals from flocks with a suspect anamnesis and $38.7 \%$ of the animals from flocks in normal health had a positive titer.

This agrees well with the observations in the field. No serious epizootics of bovine chlamydial pneumonia have been observed in Finland since the spring of 1969.

The titers in the present study were rather low and in most cases typical of exposure to an infective organism long before the sampling. The titer values and the incidence of positive sera agree well with results reported previously and show the ubiquity of Chlamydiae in domestic mammals. Their species spectrum among different mammals including man and their significance in the aetiology of various diseases in these species have not yet been explained and offer a very interesting subject of study.

\section{REFERENCES}

Bassan, T. \& N. Ayalon: Abortion in dairy cows with epizootic bovine abortion agent (Chlamydia). Amer. J. vet. Res. 1971, 32, 703710.

Eddie, B., K. F. Meyer, F. L. Lambrecht \& D. P. Furman: Isolation of Ornithosis bedsoniae from mites collected in turkey quarters and from chicken lice. J. infect. Dis. 1962, 110, 231-237.

Eddie, B., F. J. Radosvski, D. Stiller \& N. Kumada: Psittacosis-lymphogranuloma venereum (PL) agents (Bedsonia, Chlamydia) in ticks, fleas and nature mammals in California. Amer. J. Epidemiol. 1969, 90, 449-460.

Enright, J. B., W. W. Sadler \& E. A. Robinson: Sporadic bovine encephalomyelitis in California. Proc. U.S. Livestock San. Ass. 1958, $62,127-135$.

Estola, T.: Chlamydia-tartuntojen esiintyminen suomalaisessa lammaskannassa. II. Serologinen vasta-ainetutkimus Chlamydiaryhmän vasta-aineiden esiintymisestä 18 lammaskatraassa. (Occurrence of Chlamydia infections in Finnish sheep stock. II. Serological study of the occurrence of antibodies to Chlamydia group antigen in 18 flocks of sheep). Suom. Eläinlääk.-L. 1970, 76, 431436. 
Estola, T. \& E. Salmela: Chlamydia-tartuntojen esiintyminen suomalaisessa lammaskannassa. I. Ensimmäinen Chlamydiaentsootian toteaminen ja taudinaiheuttajan eristys. (Occurrence of Chlamydia infections in Finnish sheep stock. I. Determination of the first Chlamydia enzootic and isolation of the agent). Suom. Eläinlääk.-L. 1970, 76, 335-342.

Fraser, G., J. Norval, A. R. Withers \& W. W. Gregor: A case history of psittacosis in the dog. Vet. Rec. 1969, 85, 54-58.

Friis, N. F.: Occurrence of antibodies against agents of the Ornithosis group in domestic animals in Denmark. Nord. Vet.-Med. 1967, $19,572-577$.

Le Gac, P.: Sclérose en plaques et zoonoses. Importance du rôle du virus de l'avortement des bovins (pararickettsiae X-14) dans l'étiopathogénie de la sclerose en plaques. (Multiple sclerosis and zoonoses. Role of the agent of epizootic bovine abortion (the Chlamydial strain X-14) in the aetiopathogenesis of multiple sclerosis). C. R. Acad. Sci. (Paris) 1972, 275, 147-148.

Gössler, R., W. Leyk \& G. Hünermund: Serologische Untersuchungen bei Rindern in Einzugsgebiet von Kabete (Kenia). I. Mitteilung: Vorkommen von Antikörpern gegen Parainfluenza-3, IBR und BVD viruses, Chlamydia und Coxiella burneti. (Serological studies on cattle in the Kabete area of Kenya. I. Occurrence of antibodies against parainfluenza-3, IBR and BVD viruses, Chlamydia and Coxiella burneti). Berl. Münch. tierärztl. Wschr. $1973,86,164-166$.

Kinjo, T. \& R. A. Bankowski: Variations among complement fixation antigens prepared from the $6 \mathrm{~B} \mathrm{C}$ ornithosis agent or from Herellea like bacteria. Avian Dis. 1966, 10, 199-207.

Krüger-Hansen-Schoop, U., G. Schoop \& R. Brödemann: Uber die Möglichkeit der Infektion eines Milkers mit Rinder-Miyagawanellen. (Studies on a possible infection of a milker with bovine Miyagawanella). Wien. tierärztl. Mschr. 1966, 53, 23-28.

$K o ̈ b l, O .:$ Untersuchungen über das Vorkommen von Miyagawanellen beim Schwein. (Studies on the occurrence of Miyagawanellae in swine). Wien. tierärztl. Mschr. 1969, 56, 332-335.

Maierhofer, C. A. \& J. Storz: Clinical and serologic response in dogs inoculated with the Chlamydial (Psittacosis) agent of ovine polyarthritis. Amer. J. vet. Res. 1969, 30, 1961-1966.

Moore, B. W. \& A. S. Cameron: Chlamydia antibodies in antarctic fauna. Avian Dis. 1969, 13, 681-684.

Popovici, V. \& F. Hiastru: Infections à Bedsonia chez les chevaux. (Bedsonia infections in the horse). Archiva vet. 1969, 6, 45-51.

Roberts, W., N. R. Crist \& P. Giroud: Human abortion associated with infection by ovine abortion agent. Brit. med. J. 1967, 4, 37-39.

Schjerning-Thiesen, K.: Demonstration of antibodies against Psittacosis-Lymphogranuloma antigen in cattle in Denmark. Nord. Vet.Med. 1964, 16, 125-127. 
Storz, J., A. K. Engster, K. P. Altera \& H. J. Olander: Behaviour of different bovine chlamydial agents in newborn calves. J. comp. Path. 1971, 81, 299-307.

Wilson, M. R. \& P. Plummer: A survey of pig sera for the presence of antibodies to the psittacosis-lymphogranuloma venereum group of organisms. J. comp. Path. 1966, 76, 427-433.

Wyman, H., C. Rigby, J. C. Wilt \& J. A. Hildes: The significance of antibody to the psittacosis-L.G.V. group antigen. Canad. J. Microbiol. 1969, 15, 1173-1178.

Young, S., J. Storz \& C. A. Maierhofer: Pathogenic features of experimentally induced Chlamydial infection in dogs. Amer. J. vet. Res. 1972, 33, 377-383.

\section{SAMMANFATTNING}

Förekomsten av antikroppar mot gruppspecifikt Chlamydia-antigen i finska får-, nöt- och hästsera.

Serologisk undersökning över förekomsten av gruppspecifika Chlamydia-antikroppar utfördes på slumpmässigt tagna serumprov av finska får, nöt och hästar. Materialet bestod av 1347 serumprov varav 432 från får, 454 från nöt och 461 från häst. Dessa prov hade sänts till laboratoriet för diverse serologiska undersökningar under åren 19681972. Av fårsera visade $9,5 \%$, nötsera $12,8 \%$ och hästsera $7,1 \%$ titern $\geq 1: 16$ i komplementbindningstest.

Inga tydliga geografiska skillnader kunde iakttagas i utbredningen av de positiva besättningarna. Den ubikvitära förekomsten av Chlamydia-infektioner hos domesticerade däggdjur och deras roll som orsakare av kliniska sjukdomar diskuteras.

(Received December 14, 1973).

Reprints may be requested from: E. Neuvonen, State Veterinary Medical Institute, P.O. Box 368, 00101 Helsinki 10, Finland. 